\title{
U.S.-Cuban Agricultural Trade: Present Realities and Future Prospects ${ }^{1}$
}

William A. Messina, $\mathrm{Jr}^{2}$

Testimony presented before the U.S. Senate Finance Committee by William A. Messina, Jr. on September 4, 2003.

Thank you, Mr. Chairman and good morning, ladies and gentlemen. It is an honor and privilege to present this testimony today and I would like to thank you for the opportunity.

Given the time constraints placed upon us for our testimony this morning, it will be very difficult to present any sort of comprehensive view of current and future U.S.-Cuban agricultural trade. Clearly there are many political and economic dimensions to this issue. As is the case with our entire research initiative on Cuban agriculture at the University of Florida, my comments this morning will focus strictly on the economic aspects of the issue of U.S.-Cuban trade. In these next few minutes, I will try to touch on a series of key points that hopefully will set the stage for further discussion. Numerous references have been included in the text of my testimony for those seeking additional information on these key points. I should add that my comments this morning are not based simply on my research, but rather on over 10 years of research by a team of scientists at the
University of Florida in collaboration with faculty from the University of Havana. ${ }^{3}$

In October of 2000, President Bill Clinton signed the Trade Sanctions Reform and Export Enhancement Act (TSRA), which allowed U.S. firms to sell food and medicine to Cuba for the first time in nearly 40 years. Actually, along with Cuba, the legislation also opened up the sale of food and medicine to Iran, Libya, North Korea, and Sudan, although Cuba was the only one of these five nations that was prohibited from receiving U.S. private-sector financing for their purchases (i.e., U.S. firms have to handle all sales to Cuba on a cash basis). In protest to this and other provisions in the legislation, the Cuban government refused to arrange any purchases from U.S. firms, with Fidel Castro stating on numerous occasions that he would not purchase "one penny's worth" of goods from the United States.

However, in November of 2001, Hurricane Michelle rolled across Cuba doing substantial damage to Cuban agriculture. The U.S. government quickly offered food aid and Cuban officials responded that they did not want aid but that they would like to purchase agricultural and food products to replenish

1. This is EDIS document FE438, a publication of the Department of Food and Resource Economics, Florida Cooperative Extension Service, UF/IFAS, University of Florida, Gainesville, FL. Published November 2003. Please visit the EDIS website at http://edis.ifas.ufl.edu.

2. William A. Messina, Jr., Coordinator of Economic Analysis, Department of Food and Resource Economics, Florida Cooperative Extension Service, UF/IFAS, University of Florida, Gainesville, FL.

The Institute of Food and Agricultural Sciences is an equal opportunity/affirmative action employer authorized to provide research, educational information and other services only to individuals and institutions that function without regard to race, color, sex, age, handicap, or national origin. For information on obtaining other extension publications, contact your county Cooperative Extension Service office. Florida Cooperative Extension Service/Institute of Food and Agricultural Sciences/University of Florida/Christine Taylor Waddill, Dean. 
their reserves. Shipments from U.S. firms began before the end of 2001 and continue today.

In 2002, U.S. agricultural and food exports to Cuba totaled just under $\$ 140$ million, raising Cuba to 49th in the rankings of the most important U.S. agricultural export markets, up from last place out of 184 nations in 1999 (United States Department of Agriculture, Economic Research Service, 2003). The Cuban government has strategically coordinated its purchases to include shipments from at least 34 U.S. states in an effort to generate maximum political impact.

U.S. agricultural exports to Cuba include a wide range of products. However, soybean oil, poultry, wheat, and corn represent more than 93 percent of the total value of Cuban agricultural and food imports from the United States for the first six months of 2003. Grains and grain products represent the largest proportion of Cuba's total agricultural and food imports from the rest of the world as well.

The value of U.S. agricultural and food exports to Cuba for the first six months of 2003 is $\$ 102$ million, nearly 40 percent ahead of the value over the same period in 2002 (U.S.Trade and Economic Council, Inc., 2003). While this suggests that U.S. export totals for 2003 may be significantly higher than the 2002 level, Cuba's continued economic difficulties raise questions as to how much of its severely limited hard currency reserves Cuba will be willing to commit to these purchases this year. U.S. exports for the month of June 2003 were 28 percent lower than values for June 2002 (U.S.Trade and Economic Council, Inc., 2003), which may well indicate a slowing of Cuba's import patterns from the United States.

The Cuban government is able to earn hard currency for a portion of the products purchased from the United States through their sale in "dollar stores" where all transactions are conducted in hard currency. Given the markups used in the dollar markets, our research estimates that the hard currency cost of Cuba's imported food products is offset by food sales in Cuba for dollars (Ross and Fernandez Mayo, 2003).
Sales of food products, as well as non-food items, in the dollar stores represent the most important method for the Cuban government to gain access to the estimated $\$ 1$ billion that Cuban-Americans send to their families in Cuba each year (Spadoni, 2003).

Nevertheless, because of Cuba's overall economic situation, even though the Cuban government has signed contracts with U.S. firms for the purchase of more food and agricultural products in 2003 than it did in 2002, the value of U.S. exports of agricultural and food products to Cuba for 2003 ultimately may not be appreciably larger than the 2002 level.

Our work in the early 1990 s projected that U.S. agricultural and food exports to Cuba could be as high as \$1 billion per year (Alvarez and Messina, 1993), and that sales of agricultural inputs, (fertilizers, pesticides, animal feed, equipment, and supplies) could reach as high as another $\$ 700$ million (Alvarez and Messina, 1992). Subsequent studies by other analysts have arrived at similar estimates, so the fundamental question does not appear to be as much an issue of "What is the sales potential?" as "How soon might we be expected to achieve that potential?" There are both political and economic responses to that question. This testimony addresses only the economic considerations.

Some have argued that a relaxation of the cash sale provisions of the TSRA legislation to allow U.S. firms to offer credit sales would significantly boost U.S. sales of agricultural and food products to Cuba. However, that fails to take into consideration the economic realities in Cuba. The Cuban economy is a shambles and it faces serious hard currency shortages as a result of its ever-escalating trade deficit.

Cuba's trade flows were more or less in balance until the early 1960s when the economy suddenly had to adjust to the shock of losing its most important trade partner, the United States. ${ }^{4}$ The immediate impact was a rapid growth in Cuba's trade deficit. However, once the Cuban economy began to be supported and subsidized by the Soviet Union, these trade deficits were not particularly important. However, with the fall of the Berlin Wall and the subsequent dissolution of the Council for Mutual 
Economic Assistance (COMECON) ${ }^{5}$ Cuba once again lost its most important trading partner and, in this case, its all-important source of economic support. At this point, the flaws in Cuba's economic system, which were responsible for generating its large trade deficits, began to manifest themselves. Foreign investment flows, net revenues from tourism, and even the aforementioned hard currency remittances from Cuban-Americans are not sufficient to offset trade deficits that increase each year and totaled nearly 3.3 billion pesos in 2002 (Anuario de Estadístico de Cuba, 2002). ${ }^{6}$ As a result, Cuba is considered an extremely high credit risk in global financial markets, with Euromoney Magazine ranking Cuba 181st out of 184 countries in their 2003 analysis of country credit risk (Euromoney Magazine, 2003). Only Somalia, Iraq, North Korea, and Afghanistan ranked lower.

Under such circumstances, it is unlikely that many U.S. firms are going to issue open credit to Cuba, so allowing credit sales alone likely would not be sufficient to dramatically increase U.S. agricultural and food exports to Cuba. Following an opening of credit sales to Cuba, the next step might be for U.S. firms to seek access to U.S. government Export Credit Guarantee programs for agricultural and food sales to Cuba. However, that would be a very contentious issue and one that would generate a great deal of animated discussion and debate on Capitol Hill.

Under present policy, discussion focuses exclusively on U.S. exports of agricultural and food products, since Cuba is not allowed to export to the United States. No one knows when the U.S. embargo of Cuba will be lifted, but such a development will open the door for two-way trade. A wide range of business opportunities will arise for U.S. firms when trade and commercial relations with Cuba are renewed, though their nature and form will vary depending upon the economic and political situation in Cuba at the time. However, no state in the nation will be impacted more significantly than Florida by a lifting of the embargo, whenever it may occur.

Business challenges also will arise for U.S. firms and Cuban entities as well. This is particularly true for Florida agriculture when you consider that Cuba's traditional agricultural production patterns and those of Florida are almost identical, with an emphasis on sugar, vegetables, citrus, and tropical fruits. While Cuban agricultural production efficiency is abysmal by U.S. standards for most all commodities, Cuba has tremendous agricultural production potential.

In the late 1980s, Cuba was one of the largest sugar producers in the world and was the world's leading sugar exporter (Alvarez and Peña Castellanos, 2001). The Cuban government has dramatically decreased its emphasis on sugar production in recent years to the point where the harvest last season was only about two million metric tons, the lowest level in over 70 years. At present, world sugar markets are well supplied and world prices are low; thus there would be little incentive in the near term for major investment in Cuba's sugar industry. Nevertheless, Cuba still has the potential to be a globally important sugar producer and exporter.

To put Cuba's winter vegetable production potential into perspective, in 1989, Cuba had nearly twice as much acreage planted to tomatoes and cucumbers as Florida (VanSickle and Messina, 1993). Even though Cuba's vegetable yields typically are only about one third of Florida's yields (Moseley, et al., 1996), it would not take much for a joint venture partner to transfer the technology to Cuba to significantly improve those yields. In fact, several foreign firms already have entered into joint venture arrangements with Cuban entities to produce vegetables and tropical fruits for sale to the tourist hotels in Cuba, in some cases using capital-intensive greenhouse production systems. ${ }^{7}$

Because of the limited domestic purchasing power of the Cuban people, major investment along this line is not likely to occur until such time as the U.S. market is open to Cuba. However, foreign firms presently investing in Cuba's agricultural sector, and indeed in all sectors of the Cuban economy, clearly have a leg up on U.S. firms.

Significant foreign investment already has taken place in Cuba's citrus industry where several foreign companies, most notably an Israeli group, have invested and provided important technological and marketing expertise to the Cubans. ${ }^{8}$ It is important to consider that, until the 2001-02 season Cuba was the 
third largest grapefruit producer in the world after the United States and Israel. Over 80 percent of U.S. grapefruit production is in Florida (Florida Agricultural Statistics Service, 2003), so Cuba's grapefruit production potential is no small consideration for Florida's grapefruit growers. Because of its climate, Cuba's citrus ripens earlier than Florida's, and at a time when there is relatively little grapefruit available from other sources in the world. This does suggest that there may be a market window during which opportunities for complementary fresh grapefruit trade may exist, at least until the U.S. harvest begins, under a post-embargo scenario.

Again, because of the climate, Cuban orange juice tends to have high ratio and poor color characteristics, which make it undesirable in the U.S. market, indicating that the demand for Cuban orange juice products in the United States post-embargo likely will be low.

Cuba was an important supplier of fresh winter vegetables to the United States through the late 1950s. A resumption of U.S.-Cuban trade may fundamentally alter the structure of the fresh winter vegetable industry in the United States to a degree that has not been since the implementation of the North American Free Trade Agreement (NAFTA) and the subsequent peso devaluation. This will not happen overnight as there are obviously Sanitary and PhytoSanitary (SPS) regulations that will need to be met before Cuba can begin exporting into the United States. These SPS issues are particularly important given the increasing experience with and concern over the introduction of invasive species of plants and organisms that detrimentally impact U.S. agriculture and the natural environment.

And even though it is not considered "agricultural production", the marine fisheries industry is a natural resource-based industry where both Cuba and Florida have important investments and production capacities. In fact, for some species, the United States and Cuba share the same fisheries resources and fishing areas in international waters. ${ }^{9}$

All of these commodities have the potential to be exported to the United States and at a time when Cuba desperately needs to generate export revenues; it will be eager to take advantage of these sorts of opportunities as soon as political conditions allow.

Also, the legal questions of compensation or restitution for expropriated farms and agricultural processing facilities will influence the speed and nature of the recovery of Cuban agriculture. Our team of researchers, however, does not possess the expertise to address these complex legal issues.

Nevertheless, following a lifting of the embargo, change will come and, as is always the case with change, there will be winners and losers. And if there is a lesson to be learned from the experience of Florida growers following NAFTA and the peso devaluation, it is that transition time will be pivotally important for U.S. firms whose business operations will be forced to change.

In summary, the issue of U.S.-Cuban trade and its impact on the U.S. economy is a complex one. Furthermore, it is a particularly sensitive issue for Florida agriculture.

For over 150 years, Cuba and the United States were extremely important trading partners, and agricultural products represented the bulk of their trade transactions. In fact, as late as 1942, a USDA report stated, "with no other country does the United States have as close economic relations as with Cuba" (Minneman, 1942, p. 13). At some point in the future, Cuba and the United States will once again be important trading partners and I expect that agricultural products will be a principal component of that trade. But we should recognize that unfettered trade with Cuba will not be a "salvation" from the low prices being experienced by U.S. agriculture, either in the near term or in the longer term.

And finally, the embargo is NOT the cause of Cuba's economic difficulties. The fundamental problem lies in Cuba's flawed economic model. The Cuban people understand markets and incentives, but until their economic system undergoes major adjustments to allow markets and incentives to more freely operate, Cuba will never reach its full economic potential. 


\section{References}

Adams, Chuck, Placido Sanchez Vega, and Anicia Garcia Alvarez. 2000. An overview of the Cuban commercial fishing industry and recent changes in management structure and objectives. Electronic Data Information Source (EDIS) FE218. Department of Food of Resource Economics, University of Florida, Gainesville, FL. http://edis.ifas.ufl.edu/FE218.

Adams, Chuck. 1998. The Cuban commercial fishing industry and implications to the Florida seafood industry of renewed trade. International Working Paper Number IWP-98-3. Department of Food and Resource Economics, University of Florida, Gainesville, FL.

Alvarez, Jose, and Lazaro Peña Castellanos. 2001. Cuba's sugar industry. Gainesville, FL: University of Florida Press.

Alvarez, Jose, and William A. Messina, Jr. 1993. Challenges and opportunities for Florida agriculture from future trade with Cuba: Preliminary findings and justification for further research. International Working Paper Number IWP-93-5. Department of Food and Resource Economics, University of Florida, Gainesville, FL.

Alvarez, Jose, and William A. Messina, Jr. 1992. Potential exports of Florida agricultural inputs to Cuba: Fertilizers, pesticides, animal feed and machinery. International Working Paper Number IWP-92-33. Department of Food and Resource Economics, University of Florida, Gainesville, FL.

Anuario Estadístico de Cuba. 2002. Oficina Nacional de Estadísticas. Ciudad de La Habana, Cuba.

Brown, Mark G. 2000. Potential impacts of Cuban citrus on Florida's citrus industry. Working Paper Series 2000-2. Florida Department of Citrus, Economic and Market Research Department, Lakeland, FL.

http://www.cubanag.ifas.ufl.edu/pdf/brown1.pdf.

Citrus summary 2001-02. 2003. Florida Agricultural Statistics Service, Orlando, Florida. http://www.nass.usda.gov/fl/rtoc0ci.htm.
Country risk rankings. Euromoney Magazine, March 2003.

Fernandez Mayo, Maria Antonia, and James E. Ross. 2000. Cuba: Foreign agribusiness financing and investment. EIectronic Data Information Source (EDIS) FE161. Department of Food and Resource Economics, University of Florida, Gainesville, FL. http://edis.ifas.ufl.edu/pdffiles/FE/FE16100.pdf.

Messina, William A., Jr. 2000. Testimony before the U.S. International Trade Commission, Washington, D.C. (September 20).

Minneman, P.G. 1942. The agriculture of Cuba. U.S. Department of Agriculture (USDA), Washington, D.C.

Moseley, Anne E., Armando Nova González, Maria Antonia Fernandez Mayo, John VanSickle, Carlos E. Jauregui, and Douglas E. Smith. 1996. The vegetable and tropical fruit industries in Cuba and Florida. International Working Paper Number IWP-96-7. Department of Food and Resource Economics, University of Florida, Gainesville, FL.

Nova González, Armando, Thomas Spreen, and Carlos Jáuregui. 2001. The citrus industry in Cuba 1994-1999. International Working Paper Number IW01-4. Department of Food and Resource Economics, University of Florida, Gainesville, FL. http://www.cubanag.ifas.ufl.edu/pdf/cubacit.pdf.

Ross, James E., and Maria Antonia Fernandez Mayo. Forthcoming in 2003. Cuba's dollar food markets and U.S. Exports. In Cuba in transition, volume 13. Washington, D.C.: Association for the Study of the Cuban Economy.

Ross, James E., and Maria Antonia Fernandez Mayo. 2001. International economic associations in Cuba's agricultural sector. In Cuba in transition, volume 11. Washington, D.C.: Association for the Study of the Cuban Economy. http://lanic.utexas.edu/project/asce/pdfs/volume11/ rossmayo.pdf.

Spadoni, Paolo. Forthcoming in 2003. The role of the United States in the Cuban economy. In Cuba in transition, volume 13. Washington, D.C.: Association for the Study of the Cuban Economy 
Spadoni, Paolo. 2001. Impact of the

Helms-Burton legislation on foreign investment in

Cuba. In Cuba in transition, volume 11. Washington,

D.C.: Association for the Study of the Cuban

Economy.

http://lanic.utexas.edu/project/asce/pdfs/volume11/

spadoni.pdf.

U.S. Cuba Trade and Economic Council, Inc.

2003. Economic Eye on Cuba. Newsletter, the week of August 11 to August 17, New York, NY.

http://www.cubatrade.org.

USDA, Economic Research Service. 2003.

Foreign agricultural trade of the United States. http://www.ers.usda.gov/Data/FATUS.

U.S. Department of State. 2003. Cuba's foreign debt. Bureau of Western Hemisphere Affairs, Washington, D.C. (July 24).

http://www.state.gov/p/wha/rls/fs/22743.htm.

VanSickle, John J., and William A. Messina, Jr. 1993. Cuba's vegetable industry. International Working Paper Number IW93-3. Department of Food and Resource Economics, University of Florida, Gainesville, FL.

\section{Additional Notes:}

3. For information on this collaborative research initiative, see the project website at http://www.cubanag.ifas.ufl.edu.

4. For historical (pre-embargo) detail on U.S.-Cuban trade, see Messina, 2000.

5. The Council for Mutual Economic Assistance (COMECON) was an intergovernmental council made up of the Soviet Union and the nations of Eastern Europe to coordinate and improve the economic integration and development of its members.

6. For additional detail on Cuba's foreign debt, see U.S. Department of State, 2003.

7. For additional information on foreign investment in Cuban agriculture, see Ross and Fernandez Mayo, 2001; Spadoni, 2001; and http://www.cubanag.ifas.ufl.edu/publications/foreign.htm.

8. For additional information on Cuba's citrus industry, see Nova González, et al., 2001; Brown, 2000; and

http://www.cubanag.ifas.ufl.edu/publications/citrus.htm.

9. For more detail on U.S.-Cuba trade issues related to marine and seafood products, see Adams, et al., 2000; Adams, 1998; and http://www.cubanag.ifas.ufl.edu/publications/marine.htm. 